\title{
Genetic and environmental causes of variation in gestation length of Jersey crossbred cattle
}

\author{
Anshuman Kumar ${ }^{1}$, Ajoy Mandal ${ }^{2}$, A. K. Gupta ${ }^{1}$ and Poonam Ratwan ${ }^{1}$
}

1. Dairy Cattle Breeding Division, ICAR-National Dairy Research Institute, Karnal, Haryana, India; 2. Animal Breeding Section, Eastern Regional Station, ICAR-National Dairy Research Institute, Kalyani, West Bengal, India. Corresponding author: Anshuman Kumar, e-mail: anshuman.nanhe@gmail.com,

AM: ajoymandal@rediffmail.com, AKG: guptaak2009@gmail.com, PR: punam.ratwan@gmail.com Received: 16-11-2015, Revised: 26-02-2016, Accepted: 04-03-2016, Published online: 06-04-2016

doi: 10.14202/vetworld.2016.351-355 How to cite this article: Kumar A, Mandal A, Gupta AK, Ratwan P (2016) Genetic and environmental causes of variation in gestation length of Jersey crossbred cattle, Veterinary World, 9(4): 351-355.

\begin{abstract}
Aim: The objective of this study was to investigate the effect of genetic and non-genetic factors and estimate the genetic parameter for gestation length (GL) of Jersey crossbred cattle.

Materials and Methods: The data included the 986 parturition records on Jersey crossbred cattle maintained at the Eastern Regional Station of ICAR-National Dairy Research Institute, Kalyani, West Bengal, India during 36 years (1978-2013). The data were analyzed applying mixed model least square technique considering the fixed effects of genetic group, season of calving, period of calving, parity of animal, birth weight, and sex of calf born from animal. The effect of sire was included as a random effect in the model.

Results: The genetic group of animal, season of calving, parity of animal, and birth weight of calf born were found to be a significant source of variation in the GL, whereas the period of calving and sex of calf did not affect this trait. Cows with $<50 \%$ and $>62.5 \%$ Jersey inheritance had the shortest and longest GLs, respectively. Cows calved in summer and rainy season had shorter GL than those calved in the winter season. Older cows in $4^{\text {th }}$ parity carried calves for longer days than the cows in $1^{\text {st }}$ parity. The increase in calf birth weight significantly $(\mathrm{p}<0.01)$ contributed to a linear increase in GL value in this study. The heritability estimate of GL was $0.24 \pm 0.08$.
\end{abstract}

Conclusion: It can be concluded that selection for lower GL without distressing future growth of calf can be used to reduce calving difficulty, but a very small standard deviation of GL limits the benefit. Moreover, more accurate prediction of calving date will help in better management and health care of pregnant animals.

Keywords: crossbred cattle, genetic and environmental factors, gestation length, heritability.

\section{Introduction}

Gestation length (GL) is one the most important traits in cow-calf operations and significantly affects cattle breeding and production. Although the phenotypic variation of GL is biologically limited and has no direct economic benefit as such, many reports have shown its high genetic correlations with birth weight [1] and dystocia [2]. Calving difficulty in cows undermines the economic viability of dairy herds due to extensive calf losses, production of weak calves, and huge veterinary cost. Furthermore, additional losses result from impaired reproductive performance of cow calved with difficulty which takes longer time and increased number of inseminations to conceive.

GL has some prospects for selection to reduce calving problems as it has moderate to high heritability [3]. Moreover, selection for shorter gestation periods will decrease the rearing period for heifers and the

Copyright: Kumar, et al. Open Access. This article is distributed under the terms of the Creative Commons Attribution 4.0 International License (http://creativecommons.org/licenses/by/4.0/), which permits unrestricted use, distribution, and reproduction in any medium, provided you give appropriate credit to the original author(s) and the source, provide a link to the Creative Commons license, and indicate if changes were made. The Creative Commons Public Domain Dedication waiver (http://creativecommons.org/ publicdomain/zero/1.0/) applies to the data made available in this article, unless otherwise stated. calving interval for cows. GL has so far received little or no attention in dairy farm operations, and there is scanty information available on genetic evaluation of this trait under Indian conditions. Furthermore, a comprehensive study regarding variation in GL with environment and level of exotic inheritance in crossbred cattle of India is lacking.

Therefore, the objective of this study was to determine the various genetic and non-genetic factors influencing GL and the estimation of the genetic parameter in Jersey crossbred dairy cattle maintained at the dairy farm of this institute. Since animals with different levels of Jersey inheritance exist; the present study was also carried out to analyze the variation in GL with genetic grades. Establishing the range of these variations is economically important, as it may reduce the costs of parentage control of individuals born out of particularly long pregnancies [4].

\section{Materials and Methods}

\section{Ethical approval}

The present study was approved by the Institutional Animal Ethics Committee of National Dairy Research Institute (NDRI).

\section{Location of study and management of animal}

The study was carried out at Eastern Regional Station of ICAR-NDRI, Kalyani, Nadia, West Bengal, 
India. Kalyani is located in the lower Gangetic basin of West Bengal. The farm is located at an average altitude of $9.75 \mathrm{~m}$ above the mean sea level on $22.59^{\prime} \mathrm{N}$ latitude and $88.29^{\prime} \mathrm{E}$ longitude. The climatic conditions and management practices at this station have been previously described [5]. Animals were raised under zero grazing loose housing system, and the nutritional requirements of the cows were met through a standardized ration of concentrate and ad libitum green fodder.

\section{Sample population, classification, and editing of data}

Insemination and calving records of Jersey crossbred cattle kept at Eastern Regional Station of ICARNDRI, Kalyani, Nadia, West Bengal, India, calved during a period of 36 years (1978-2013) were used. The information was collected from AI records and reproduction sheets maintained at different sections of institute, viz., record room of Animal breeding section and Cattle Yard, ERS of ICAR-NDRI, Kalyani. GL was determined as the interval from the date of the last insemination to the date of subsequent calving. To ensure the normal distribution, the outliers were removed, and data within the range of mean \pm 2 standard deviation were only considered. Since there were animals with different levels of Jersey inheritance, the genetic group of each animal was deduced after back tracing of the pedigree of animal. To evaluate the effect of various genetic and non-genetic factors on GL, the data were grouped into different classes to be used as fixed effects. The data were classified as shown in Table-1. The GL of heifers was assigned first parity in this study. The random effect of sire was also included in the model. Only those gestations which terminated in single births of normal calves were considered in the study. Moreover, animals with abortion, stillbirth, or premature birth records were not included in the present study. For the genetic studies, sires having three or more daughters were only considered.

\section{Statistical analysis}

The effects of genetic and non-genetic factors on reproductive traits were carried out by least square analysis of variance using the technique described by Harvey [6]. Duncan's multiple range test as modified by Kramer [7] was used for testing the differences between least squares means between sub-classes. Genetic parameters were estimated using Model 2 of Mixed Model Least square and Maximum Likelihood, PC-2 Version Computer Program [6].

The following model was used:

Where,

$$
\begin{aligned}
\mathrm{Y}_{\mathrm{ijk} k m n o p}= & \mu+\mathrm{S}_{\mathrm{i}}+(\mathrm{GG})_{\mathrm{j}}+(\mathrm{Sea})_{\mathrm{k}}+\mathrm{P}_{\mathrm{l}}+(\mathrm{Pa})_{\mathrm{m}}+(\mathrm{Bw})_{\mathrm{n}} \\
& (\mathrm{Sex})_{\mathrm{o}}+\mathrm{e}_{\mathrm{ijk} \text { lmnop }}
\end{aligned}
$$

$\mathrm{Y}_{\mathrm{ijklmnop}}=$ Phenotypic value of trait on the $\mathrm{p}^{\text {th }}$ animal

$\mu=$ Overall mean

$\mathrm{S}=$ Random effect of $i^{\text {th }}$ Sire

$(\mathrm{GG})_{\mathrm{i}}=$ Fixed effect of $\mathrm{j}^{\text {th }}$ Genetic group (1-8)

$(\mathrm{Sea})_{\mathrm{k}}=$ Fixed effect of $\mathrm{k}^{\text {th }}$ season of calving (1-3)
Table-1: Classification of data for genetic and environmental factors.

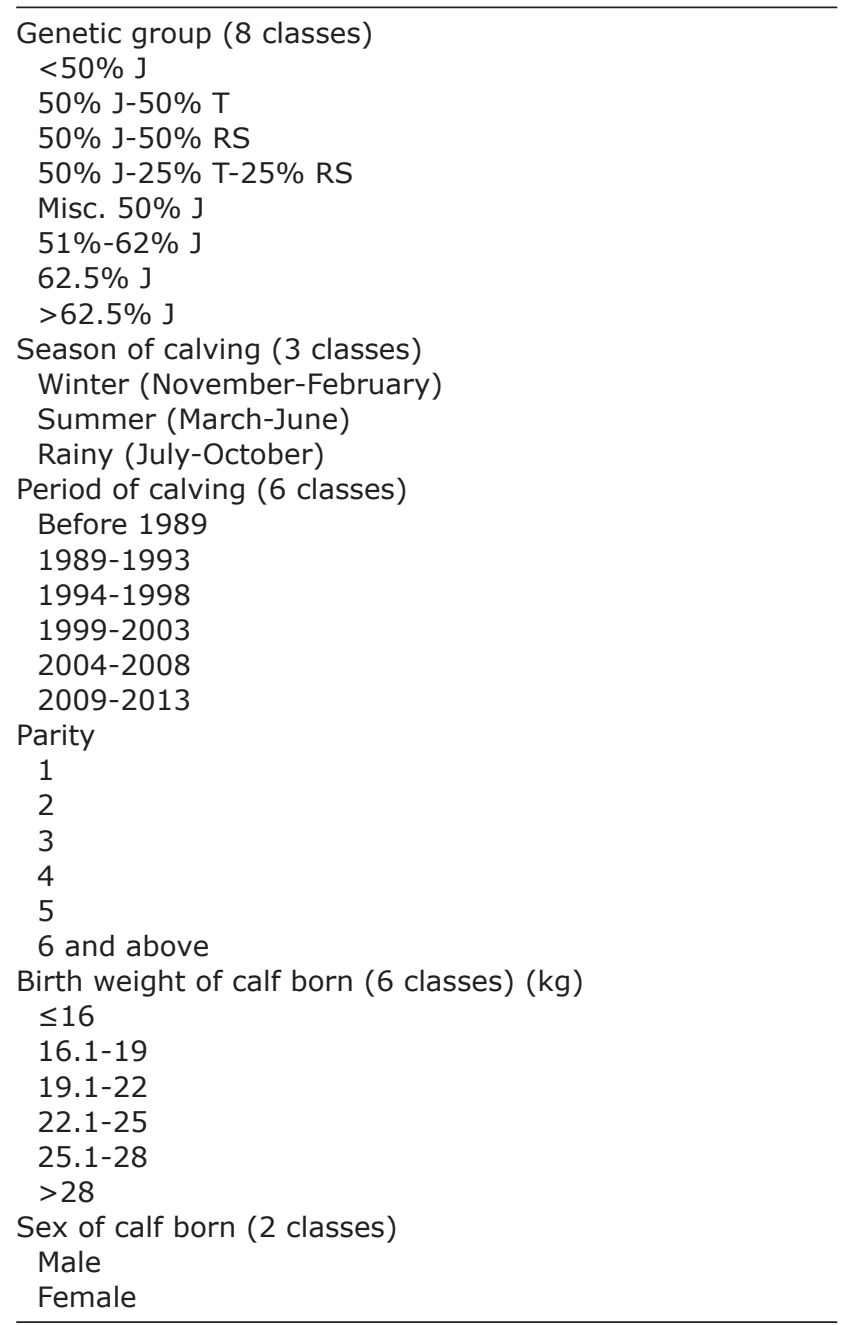

J=Jersey, T=Tharparkar, RS=Red Sindhi, Misc. $=$ Miscellaneous

$\mathrm{P}_{1}=$ Fixed effect of $\mathrm{l}^{\text {th }}$ period of calving (1-6)

$(\mathrm{Pa})_{\mathrm{m}}=$ Fixed effect of $\mathrm{m}^{\text {th }}$ parity of cow (1-6)

$(\mathrm{Bw})_{\mathrm{n}}=$ Fixed effect of birth weight of calf born (1-6)

$(\mathrm{Sex})_{\mathrm{o}}=$ Fixed effect of sex of calf born (1-2)

$\mathrm{e}_{\mathrm{ijk} \mid \mathrm{mnop}}=$ Random error $\sim \operatorname{NID}\left(0, \sigma_{\mathrm{e}}^{2}\right)$

\section{Results and Discussion}

Frequency distribution of the GL is presented in Figure-1 - The curve is skewed toward a length of gestation of over 285 days. The mean GL recorded in Jersey crossbred cattle was $280 \pm 0.25$ days (Table-2), with a range of 260-301 days and coefficient of variation of $2.19 \%$. It is in agreement with the other reports in Jersey crossbred cattle [8,9]. Norman et al. [10] also reported similar results for GL with mean value of 280 days for Jersey cattle. However, the mean GL of animals in this study was higher than the finding of Bhutkar et al. [11], Mondal et al. [12], and Varaprasad et al. [13] who obtained the values of 274.93 , 275, and 276.89 days, respectively, in crossbred cattle of India. 


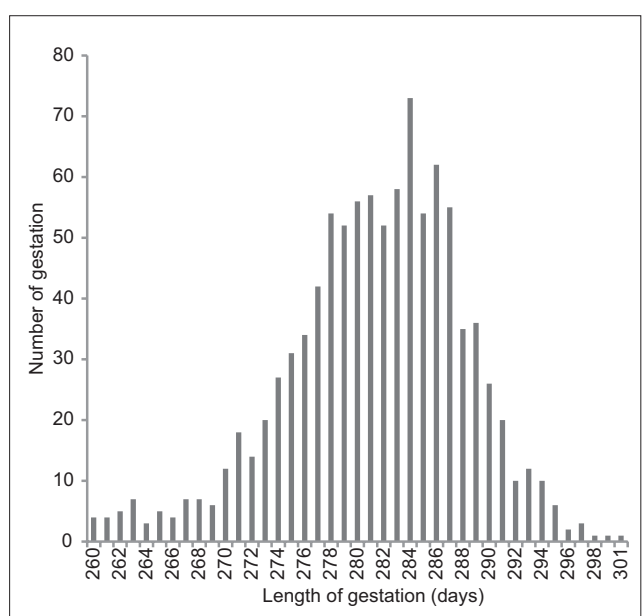

Figure-1: Frequency distribution of gestation length in Jersey crossbred cattle.

Table-2: Degrees of freedom, mean squares, $F$ values and significance of sources of variation affecting gestation length in Jersey crossbred cattle.

\begin{tabular}{lcccc}
\hline $\begin{array}{l}\text { Source of } \\
\text { variation }\end{array}$ & $\begin{array}{c}\text { Degrees of } \\
\text { freedom }\end{array}$ & $\begin{array}{c}\text { Mean } \\
\text { square }\end{array}$ & F value & p \\
\hline Sire & 39 & 81.60 & 2.30 & 0.0000 \\
Genetic group & 7 & 119.63 & 3.37 & 0.0016 \\
Season & 2 & 254.45 & 7.16 & 0.0008 \\
Period & 5 & 32.10 & 0.90 & 0.4796 \\
Parity & 6 & 97.99 & 2.76 & 0.0176 \\
Birth weight of calf & 5 & 1131.38 & 31.83 & 0.0000 \\
Sex of calf & 1 & 67.23 & 1.89 & 0.1694 \\
Error & 921 & 35.54 & & \\
\hline
\end{tabular}

\section{Effect of sire}

Sire had highly significant $(\mathrm{p}<0.01)$ effect on length of gestation of crossbred cattle in the present study (Table-2).

\section{Effect of genetic group}

The gestation period of animals was significantly $(p<0.01)$ varied among the animals of different genetic groups in this study (Tables-2 and 3) which was in conformity with the findings of Norman et al. [10], who reported that GL is typical for breed in their study on different breeds of cattle. The present study revealed that cows with $<50 \%$ and $>62.5 \%$ Jersey inheritance had the shortest $(279.10 \pm 1.01$ days $)$ and longest (283.12 \pm 0.94 days) gestation periods, respectively. The results were almost similar to Bahmani et al. [14], who reported lowest GL to $25 \%$ exotic inheritance group, whereas the highest value was related to $50 \%$ and $\geq 75 \%$ group. The longer GL of animals having Jersey inheritance of more than $62.5 \%$ in the current study may be due to the more milk production potential of cows with more exotic inheritance as there may be an existence of a positive correlation between milk yield and GL of animals [15]. However, the present findings were different from Mondal et al. [12], who reported the non-significant influence of genetic group on GL of animals.

\section{Effect of season of calving}

The influence of season of calving was significant $(\mathrm{p}<0.01)$ with cows calved in summer and rainy season had shorter GL than those calved in the winter season (Tables-2 and 3). Similar findings were reported by Petrović et al. [16], Bakir et al. [17], and Melaku et al. [18], who reported that shorter GL were associated with high summer temperature. In contrast, Silva et al. [15] found no difference in GL between warm and cool seasons in Florida. The shorter GL in summer and rainy season in the present study may be attributable to dietary changes and high temperature during the last phase of gestation which speeds up the parturition process [19].

\section{Effect of period of calving}

The period of calving of animal had no significant influence on GL in this study (Table-2). The present results were in agreement with Turkyilmaz [20], who reported the non-significant difference between GLs of Holstein cows calved in different years. However, there was a total linear change of 3.28 days over 39 years. This finding is quite similar to Silva et al. [15] who noticed a significant increase of 4 days over a period of 50 years in GL of Guernsey, Holstein, and Jersey cows at several Florida-based farms. Bhutkar et al. [11] also reported a significant effect of period on GL in crossbred cattle. This gradual increase in GL over the years could be attributed to the sharp rise in production level.

\section{Effect of parity}

In the present study, GL of animals was significantly $(\mathrm{p}<0.05)$ influenced by parity of animal at breeding (Table-2). Animals in $4^{\text {th }}$ parity had the longest GL (281.31 \pm 0.76 days), whereas heifers and cows of $5^{\text {th }}$ parity onward had the lowest GL. This study was similar to the study of Petrović et al. [16] and Nogalski and Piwczyński [21] who reported a longer gestation period in older cows with a significant difference of 1 day between $1^{\text {st }}$ and $3^{\text {rd }}$ calving. Results of the present study were also consistent with earlier studies $[17,19,22]$ on crossbred cattle, who observed that parity of dam significantly affects GL in cattle with heifers having shorter GL than cows. Moreover, older cows carried their calves for longer days than younger cows because of the relatively large uterus. However, Messine et al. [23] and Menon et al. [24] reported no difference in GL between heifers and cows.

\section{Effect of birth weight of calf}

The increase in calf birth weight significantly $(\mathrm{p}<0.01)$ contributed to a linear increase in GL value in this study (Table-3). In the dams of heaviest calves $(>28 \mathrm{~kg})$, on an average GL of animals was 9.54 days longer than dams with lightest calves $(\leq 16 \mathrm{~kg})$. The results were consistent with findings of Nogalski and Piwczyński [21] and Nadarajah et al. [25] who reported a difference of 3.7 and 3.9 days, respectively, between cows with large and small fetuses. Cows with 
Table-3: Least squares means ( \pm SE) for GL of Jersey crossbred cattle.

\begin{tabular}{|c|c|c|}
\hline Parameters & $\mathbf{N}$ & GL (days) \\
\hline Overall mean & 986 & $280.25 \pm 0.54$ \\
\hline \multicolumn{3}{|l|}{ Genetic group } \\
\hline$<50 \% \mathrm{~J}$ & 78 & $279.10^{\complement} \pm 1.01$ \\
\hline $50 \% \mathrm{~J}-50 \% \mathrm{~T}$ & 182 & $279.76^{c} \pm 1.09$ \\
\hline $50 \% \mathrm{~J}-50 \% \mathrm{RS}$ & 82 & $281.36^{\mathrm{ab}} \pm 0.86$ \\
\hline $50 \% \mathrm{~J}-25 \% \mathrm{~T}-25 \% \mathrm{RS}$ & 133 & $279.35^{c} \pm 0.84$ \\
\hline Misc. $50 \% \mathrm{~J}$ & 280 & $279.47 c \pm 0.65$ \\
\hline $51 \%-62 \% \mathrm{~J}$ & 80 & $279.23^{c} \pm 0.93$ \\
\hline $62.5 \% \mathrm{~J}$ & 63 & $280.64^{\mathrm{bc}} \pm 1.00$ \\
\hline$>62.5 \% \mathrm{~J}$ & 78 & $283.12^{\mathrm{a}} \pm 0.94$ \\
\hline \multicolumn{3}{|l|}{ Season } \\
\hline Winter (November-February) & 305 & $281.16^{a} \pm 0.62$ \\
\hline Summer (March-June) & 333 & $280.29^{a b} \pm 0.61$ \\
\hline Rainy (July-October) & 348 & $279.31^{\mathrm{b}} \pm 0.60$ \\
\hline \multicolumn{3}{|l|}{ Period } \\
\hline Before 1989 & 69 & $278.81 \pm 1.60$ \\
\hline 1989-1993 & 109 & $278.84 \pm 1.21$ \\
\hline 1994-1998 & 169 & $279.62 \pm 0.83$ \\
\hline 1999-2003 & 181 & $280.14 \pm 0.83$ \\
\hline 2004-2008 & 219 & $282.02 \pm 1.07$ \\
\hline 2009-2013 & 239 & $282.09 \pm 1.42$ \\
\hline \multicolumn{3}{|l|}{ Parity } \\
\hline 1 & 253 & $279.65^{b} \pm 0.69$ \\
\hline 2 & 232 & $280.30^{\mathrm{ab}} \pm 0.66$ \\
\hline 3 & 171 & $281.28^{a} \pm 0.69$ \\
\hline 4 & 119 & $281.31^{\mathrm{a}} \pm 0.76$ \\
\hline 5 & 87 & $279.45^{b} \pm 0.85$ \\
\hline 6 and above & 124 & $279.54^{b} \pm 0.88$ \\
\hline \multicolumn{3}{|l|}{ Birth weight of calf $(\mathrm{kg})$} \\
\hline$\leq 16$ & 45 & $274.49^{\mathrm{e}} \pm 1.05$ \\
\hline 16.1-19 & 100 & $276.62^{d} \pm 0.80$ \\
\hline $19.1-22$ & 251 & $280.00^{`} \pm 0.62$ \\
\hline $22.1-25$ & 322 & $282.01^{\mathrm{b}} \pm 0.60$ \\
\hline $25.1-28$ & 198 & $284.03^{a} \pm 0.66$ \\
\hline$>28$ & 70 & $284.38^{\mathrm{ab}} \pm 0.89$ \\
\hline \multicolumn{3}{|l|}{ Sex of calf } \\
\hline Male & 512 & $280.53 \pm 0.58$ \\
\hline Female & 474 & $279.98 \pm 0.58$ \\
\hline
\end{tabular}

Means with different superscripts in columns within fixed effects differ significantly $(p<0.05)$. GL=Gestation length, SE=Standard error, J=Jersey, $\mathrm{T}=$ Tharparkar, RS $=$ Red Sindhi

heavier calves could result in increased risk of dystocia and stillbirth [26,27].

\section{Effect of sex of calf}

The present study revealed the non-significant effect of sex of calf on GL of the dam. Similar non-significant effects of sex of calf on GL were noticed by Melaku et al. [18]. However, several published reports were in disagreement with the present study, which showed that sex of calf significantly affects GL, with male calves gestated 1-3 days longer than females $[10,24,26]$.

\section{Heritability estimate}

Heritability for GL of Jersey crossbred cattle in the current study was $0.24 \pm 0.08$ within the range of previous studies $[15,21]$ who estimated the heritability of 0.22 and 0.21 , respectively, but the estimate lower than this value was reported by Johanson et al. [28]. The moderate heritability suggests the genetic possibility of changing the trait. However, selection for GL is undesirable, as extreme values of this trait may lead to calving difficulties and stillbirth [29]. Furthermore, the possibility of reducing the inter-calving period through a selection of shorter GL is little due to small genetic standard deviation.

\section{Conclusions}

The genetic group of animal, season of calving, parity of animal, and birth weight of calf were found to be significant sources of variation in the GL of the Jersey crossbred cattle, whereas the period of calving and sex of calf did not affect this trait. Cows with $<50 \%$ and $>62.5 \%$ Jersey inheritance had the shortest and longest GLs, respectively. Shorter GL were also associated with the high temperature of summer and rainy season. Older cows carried calves for a longer period than did younger cows; however, it was not true for extremely old cows. Calves born from shorter GL present lower birth weight, which could result in less calving difficulty. Thus, the selection for lower GL without distressing future growth traits in dairy cattle improvement program can be used to reduce dystocia which will further increase the probability of number of live calves born in the herd. However, in spite of higher heritability of GL, the standard deviation of GL was very small which limit the benefit of selection for GL. Moreover, selection for GL should be done with caution as both longer and shorter gestation periods contribute to a higher number of stillbirths [21]. More accurate prediction of calving dates can help dairy producers to meet management requirements of pregnant animals and to administer better healthcare during high-risk phases of animals' lives.

\section{Authors' Contributions}

AM has planned the study. AK recorded the information and analyzed the data. AKG acted as an advisory committee member and contributed immensely right from the start to end of the experiment. PR provided help in the analysis of data. AK drafted and revised the manuscript under the guidance of AM. All authors read and approved the final manuscript.

\section{Acknowledgments}

The authors are indebted to the Director and Vice Chancellor, ICAR-NDRI, Karnal, Haryana for providing the infrastructure facilities to carry out the study. The authors would also wish to acknowledge the contribution of the former In-charges and staffs of the cattle section of Eastern Regional Station of ICAR-NDRI for management and recording of animals over the years.

\section{Competing Interests}

The authors declare that they have no competing interests.

\section{References}

1. Bourdon, R.M. and Brinks, J.S. (1982) Genetic, environmental and phenotypic relationships among gestation 
length, birth weight, growth traits and age at first calving in beef cattle. J. Anim. Sci., 55: 543-553.

2. Nadarajah, K. and Burnside, E.B. (1989) Relationships among gestation length, calving easy and calf mortality in Ontario Holstein cattle. J. Anim. Sci., 67 Suppl: 87.

3. Goyache, F. and Gutiérrez, J.P. (2001) Heritability of reproductive traits in Asturiana de los valles beef cattle breed. Arch. Tierz., 44: 489-496.

4. Sobek, Z., Nienartowicz-Zdrojewska, A., Różańska-Zawieja, J. and Siatkowski, I. (2015) The evaluation of gestation length range for different breeds of Polish dairy cattle. Biom. Lett., 52(1): 37-45.

5. Mandal, A., Roy, P.K., Ghosh, M.K., Chatterjee, A. and Das, S.K. (2013) Genetic and environmental effects on first lactation traits of Jersey crossbred cattle in an organized herd of Eastern India. Indian J. Dairy Sci., 66(2): 130-133.

6. Harvey, W.R. (1990) Users' Guide for LSMLMW and MIXMDL, Mixed Model Least Squares and Maximum Likelihood Computer Program. PC-2 Version. The Ohio State University, Columbus, USA.

7. Kramer, C.Y. (1957) Extension of multiple range tests to group correlated adjusted means. Biometrics., 13: 13-18.

8. Nahar, T.N., Islam, M. and Hashath, M.A. (1992) A comparative study on the performance of $\mathrm{F}_{1}$ crossbred cows under rural conditions. Asian. Aust. J. Anim., 5: 435-338.

9. Qureshi, M.A., Javed, K., Jarral, Z.A. and Khan, S.A. (2008) Environmental factors affecting performance traits of crossbred and local dairy cows at Mirpur Azad Jammu and Kashmir. Pak. J. Agric. Sci., 45: 362-371.

10. Norman, H.D., Wright, J.R., Kuhn, M.T., Hubbard, S.M., Cole, J.B. and Van Raden, P.M. (2009) Genetic and environmental factors that affect gestation length in dairy cattle. J. Dairy. Sci., 92(5): 2259-2269.

11. Bhutkar, S.S., Thombre, B.M. and Bainwad, D.V. (2014) Studies on effect of non-genetic factors on reproduction traits in Holstein friesian x deoni cows. IOSR. J. Agric. Vet. Sci., 7(12): 15-19.

12. Mondal, S.C., Alam, M.M., Rashid, M.M., Ali, M.Y. and Hossain, M.M. (2005) Comparative study on the productive and reproductive performance of different dairy genotypes reared in Bangladesh Agricultural University Dairy Farm. Pak. J. Nutr., 4(4): 222-225.

13. Varaprasad, A.R., Raghunandan, T., Kumar, M.K. and Prakash, M.G. (2013) Studies on the reproductive performance of Jersey x Sahiwal cows in chittoor district of Andhra pradesh. Int. J. Agric. Sci. Vet. Med., 1(1): 52-57.

14. Bahmani, H.R., Aslaminejad, A.A., Tahmoorespur, M. and Salehi, S. (2011) Reproductive performance of crossbred dairy cows under smallholder production system in Kurdistan province of Iran. J. Appl. Anim. Res., 39(4): 375-380.

15. Silva, H.M., Wilcox, C.J., Thatcher, W.W., Becker, R.B. and Morse, D. (1992) Factors affecting days open, gestation length, and calving interval in Florida dairy cattle. J. Dairy Sci., 75(1): 288-293.

16. Petrović,M.D.,Bogdanowić,V.,Bogosavljević-Boškowić,S. and Dokovoć, R. (2010) Effect of systematic factors on gestation length in simmental cows. Acta. Agric. Serb., XV(29): 31-37.

17. Bakir, G. and Cilek, M. (2009) A research on reproductive traits of Holstein cattle reared at tahirova state farm in Balikesir province in Turkey. J. Anim. Vet. Adv., 8(11): 2383-2387.

18. Melaku, M., Zeleke., M. Getinate, M. and Mengistie, T. (2011) Reproductive performances of fogera cattle at metekel cattle breeding and multiplication ranch, North West Ethiopia. Online J. Anim. Feed. Res., 1(3): 99-106.

19. McClintock, S., Beard, K., Gilmour, A. and Goddard. M. (2003) Relationships between calving traits in heifers and mature cows in Australia. Interbull. Bull., 31: 102-106.

20. Turkyilmaz, M.K. (2005) Reproduction characteristics of Holstein cattle reared in a private dairy cattle enterprise in Aydin. Turk. J. Vet. Anim. Sci., 29: 1049-1052.

21. Nogalski, Z. and Piwczyński, D. (2012) Association of length of pregnancy with other reproductive traits in dairy cattle. Asian. Aust. J. Anim., 25(1): 22-27.

22. Goyache, F., Fernández, I., Alvarez, I., Royo, L.J. and Gutiérrez, J.P. (2002) Gestation length in the Asturiana delos valles beef cattle breed and its relationship with birth weight and calving ease. Arch. Zootec., 51: 431-439.

23. Messine, O., Schwalbach, L.J.M., Mbah, D.A. and Ebangi, A.L. (2007) Non-genetic factors affecting gestation length and postpartum intervals in gudali zebu cattle of adamawa highlands of Cameroon. Tropicaltura, 25(3): 129-133.

24. Menon, K., Rojan, P.M., Kumar, N.S. and Prasad, V. (2014) Factors affecting birth weight and gestation period of crossbred cattle and relationship between them in intensive farming system. Indian. J. Dairy Sci., 67(2): 158-161.

25. Nadarajah, K., Burnside, E.B. and Schaeffer, L.R. (1989) Factors affecting gestation length in Ontario Holsteins. Can. J. Anim. Sci., 69(4): 1083-1086.

26. Crews, D.H., Jr. (2006) Age of dam and sex of calf adjustments and genetic parameters for gestation length in Charolais cattle. J. Anim. Sci., 84: 25-31.

27. Jamrozik, J. and Miller, S.P. (2014) Genetic evaluation of calving ease in Canadian Simmentals using birth weight and gestation length as correlated traits. Livest. Sci., 162: 42-49.

28. Johanson, J.M., Berger, P.J., Tsuruta, S. and Misztal, I. (2011) Bayesian threshold-linear model evaluation of perinatal mortality, dystocia, birth weight, and gestation length in a Holstein herd. J. Dairy Sci., 94: 450-460.

29. Olson, K.M., Cassel, B.G., McAllister, A.J. and Washburn, S.P. (2009) Dystocia, stillbirth, gestation length, and birth weight in Holstein, Jersey, and reciprocal crosses from a planned experiment. J. Dairy Sci., 92: 6167-6175. 